\title{
Internationalization of Renewable Energy Companies: In Search of Gestalts
}

\author{
Sebastian Günther Koch ${ }^{1} \&$ Reinhard Michael Meckl ${ }^{1}$ \\ ${ }^{1}$ Department of International Management, University of Bayreuth, Bayreuth, Germany \\ Correspondence: Reinhard Michael Meckl, Chair of International Management, University of Bayreuth, \\ Universitätsstraße 30, D-95440 Bayreuth, Germany. Tel: 49-921-55-4861. E-mail: \\ reinhard.meckl@uni-bayreuth.de
}

Received: December 18, 2013

Accepted: January 26, 2014

Online Published: February 24, 2014

doi:10.5539/ibr.v7n3p34

URL: http://dx.doi.org/10.5539/ibr.v7n3p34

\begin{abstract}
Internationalization is an essential component of corporate strategy. The present study, which focuses on the renewable energy sector, is an empirical investigation into the prognostic strength of the Gestalt Approach of International Business Strategies (GAINS approach) for the identification of potentially successful strategies for internationalization, focusing on the mode of market entry.

The results show that (1) the GAINS approach has a high prognostic potential for successful internationalization strategies, since (a) FIT configurations represent Gestalts, i.e. they show significantly higher success of internationalization than other configurations, (b) consistent configurations show significantly higher success than congruent configurations and (c) MISFIT configurations prove to be the least successful configuration. (2) Although FIT configurations promise the highest success of internationalization, the results indicate that many companies do not enter into fit configurations. Yet, it was proven, that (3) CONSISTENT configurations are preferred compared to CONGRUENT configurations and (4) MISFIT configurations are significantly being avoided.
\end{abstract}

Keywords: configurations, internationalization, market entry mode, renewable energies

\section{Introduction}

Internationalization is a significant component of corporate strategy for many companies. Companies operating internationally have a competitive edge with regard to volume effect and knowledge, as well as a cost-effective access to resources. Internationalisation is thus an essential component for a sustainable and strategically stable position of a company (Porter, 1986). Selection of promising modes of market entry and cultivation for a foreign market is an integral aspect of internationalisation (Anderson \& Gatignon, 1986; Hill, Huang, \& Kim, 1990; Agarwal \& Ramaswami, 1992). With regard to multiple forms of market entry and cultivation for the foreign market (Meckl, 2010) companies must try to identify the most potentially successful strategy for every foreign market.

The Gestalt Approach of International Business Strategies (GAINS approach), evolved from the configuration theory (Miles \& Snow, 1984; Miller \& Mintzberg, 1983; Miller, 1981, 1987; Miller \& Friesen, 1980, 1984), is a research approach, by means of which the success of marketing strategies can be predicted (Macharzina \& Engelhard, 1991). On the basis of empirical investigations, different marketing techniques can be evaluated to derive successful strategies. Investigations to date were generally concerned with a variety of industries (Roth, 1992; Strothe, 2006). The heterogeneity of the research results for international management to date, however, point to the conclusion that concrete strategies can best be derived from specific industrial sector investigations (Jakopin, 2006,; Morschett, Swoboda, \& Schramm-Klein, 2008 \& 2010). Thus, for the purpose of validation and operationalization of the GAINS approach, there is a need for empirically-based studies, focusing on specialised industrial sectors.

The renewable energy (RE) sector in Germany is particularly suitable for this purpose. Component manufacturers in the wind power and photovoltaic industry were and still are confronted with the challenge of an increasing pressure for internationalization (cf. Section 2). Due to a slump in sales in the domestic market, induced by market changes, the German supplier market shifted to a global, highly competitive market with 
limited state subsidies, determined by consumer demand. Furthermore, especially in the photovoltaic sector, there was heightened international competition on account of an increase in competitors from low cost regions. As a result, a massive decline in production capacity utilisation could be observed. To counteract this trend, manufacturers were forced to open up new markets or to enforce cultivation of existing foreign markets. In the rapidly changing market environment, export as preferred mode of market entry by the German renewable energy sector to date, forfeited efficiency and efficacy in the wake of increasing competition. Increasing foreign competition required a more active marketing on site. In order to maintain competitiveness, the renewable energy component manufacturers were forced to revise their internationalization strategies and to identify the most promising marketing strategies.

Regarding the high relevance of internationalization for the renewable energy sector, research about this topic is in its infancy. The present study is trying to close this gap. The objective is to indicate promising strategies for foreign market entry and cultivation in the renewable energy sector, with use of the GAINS approach for hypothetical formulation and empirical verification. The results are presented as follows:

- Section 2 highlights the particular relevance of internationalization for the RE sector, by means of an industry analysis.

- Section 3 outlines the theoretical basis of the research approach by introduction of the GAINS approach. As an explanation for corporate-related factors, the dynamic capabilities view is applied as an additional theory.

- Section 4 presents the research model as well as the related hypotheses.

- Section 5 describes the empirical analysis and outlines the results.

- Section 6 presents and discusses the findings, limitations and further research questions.

\section{The Renewable Energies Sector in Germany}

Until 2008 the renewable energies (RE) sector was characterised by over-proportional growth and surplus of demand. Whereas the somewhat more mature wind power sector increased by over $25 \%$ p.a. (Krohn, Morthorst, \& Awerbuch, 2009; Molly, 2009; Zervos \& Kjaer, 2008; Pullen, Qiao, \& Sawyer, 2008), the photovoltaic (PV) sector, still in its infancy, attained a growth rate of over $45 \%$ p.a. (Fontaine et al., 2009). In most countries, demand was controlled by governments. Especially in Germany, subsidies, in the form of guaranteed feed-in tariffs, had a considerable effect. Under the umbrella of state pricing policy, German entrepreneurs very quickly emerged as providers of renewable energy systems and the German market became the largest PV and wind energy market in the world. The RE sector, with its high growth rate, limited market risks, and high profit margins, became an attractive object for capital investment.

The end of 2008 witnessed a change in these paradisiacal conditions. Due to the economic crisis, the demand for photovoltaic and wind energy facilities declined in Germany and other countries. The recently begun huge capacity expansion in the PV sector led to overcapacity. Increasing competition through cheaper manufacturers in Asia heightened the competitive intensity in the PV sector as well as in the wind energy sector. As a result, component prices fell. Since this meant increased yield at the operating facilities, politicians strove to reduce the guaranteed electricity purchasing price (e.g., Mrusek, 2010; Murphy, Stratmann, \& Weishaupt, 2010). Reducing the feed-in tariffs inevitably led to a fall in demand. The RE sector was therefore moving over to a more challenging market with higher competitive intensity. Future growth of the RE sector shifted outside Germany to the USA and Asia. Except for the new German off-shore wind energy market, growth most likely could have been realized by foreign market expansion.

Regarding this development future prospects for the German RE sector were indeed heterogeneous. Whereas some leading companies already had solid revenues abroad, small and medium-sized companies operating in the two branches served foreign markets only sporadically or focused on fewer markets. The result was a high economic dependency on very few markets. Thus, the turnover of many medium-sized photovoltaic companies, recently booming in the Spanish market, had fallen drastically as a result of the sudden subsidy caps. The risk issue was pushing several domestic companies further into internationalization to diminish dependency and spread the risks. Larger companies also reflected considerable shortcomings with regard to internationalization. Some leading wind power plant manufacturers had hesitated to tap the future markets in the USA by limiting foreign business activities to export, handing over strategic advantages to their competitors, by way of stronger engagement in foreign markets. The same was true for leading PV companies, who in the past served the foreign market primarily as exporters, leaving the market potential untapped through a somewhat defensive internationalization policy. Others expanded considerably in a "one-fits-all" strategy by opening sales companies 
in most diverse countries. As a result of inadequate competencies and resources and inefficient market strategies, they had to withdraw from many foreign markets due to lack of success. With regard to the urgency for cost reducing off-shore production in Asia only few companies in the RE sector already had ventured this promising step.

Against this background, it is obvious that many companies operating in the German RE sector had the need to increase their international business by opening up new markets or adapting their strategies to suit changes in existing foreign markets. All of the German companies operating in the RE sector, with young start-up companies, small, medium-sized companies and market leaders, with turnovers of over $1 \mathrm{bn}$ euros, required internationalization strategies which best tap current and forthcoming market potential. By investigating the prognostic strength of the GAINS approach the present study wants to provide these RE companies with a method for the definition of successful internationalization strategies, thereby focusing on the mode of market entry.

\section{Theoretical Fundamentals}

\subsection{Definition of Internationalization Strategy}

Internationalization strategies are measures to build up new or to adapt existing business activities in foreign markets. The measures are long-term oriented and consider both company and market specific characteristics. The overall target is to ensure the successful continuity of the firm (Jakopin, 2006; Kutschker \& Schmid, 2006). Internationalization strategy can be divided up into three major pillars: target market selection, mode of market entry or cultivation and timing strategy (Welge \& Holtbrügge, 2006). Target market selection especially is dependent on the two dimensions market attractiveness and market barriers (Meckl, 2010; Backhaus, Büschken, \& Voeth, 2003). Market attractiveness and market barriers are not only key determinants of the target market selection decision. They also have a major impact on the choice of market entry and cultivation mode because of their influence on the proper level of resource commitment, both tangible and intangible, and level of control (Agarwal \& Ramaswami, 1992; Hill, Hwang, \& Kim, 1990; Malhotra, Agarwal, \& Ulgado, 2003).

Market entry modes can be divided into three general categories that differ in the level of control over the foreign business operation (Buckley \& Casson, 2002; Anderson \& Gatignon, 1986; Calvet, 1981), the resource commitment (Vernon, 1983) as well as the "dissemination risk" (Hill \& Kim, 1988), and general risk of losses (Vernon, 1983; Anderson \& Gatignon, 1986). The three different forms (Kotler, 1988) are export, co-operations, and foreign direct investment (FDI). Export represents the entry mode with the lowest level of control, resource commitment and risk, while FDI, for example by greenfield investment or acquisition, presents the entry mode with the highest degree of control, resource commitment and risk. Co-operations like joint ventures (JV) or licensing are hybrid, contract-based entry modes, allocated in between. With the right set of resources, competencies, and capabilities, the risk of a market entry mode, i.e. the firm's internal uncertainty, can be diminished (Johanson \& Vahlne, 1977; Erramilli, 1991). Timing is the third pillar of internationalization strategy. The timing strategy includes the decision about the point in time a firm enters a foreign market and the decision about the market entry sequence across various countries (Pues, 1994).

Although all three pillars are important, the market entry mode or mode of market cultivation is the main component of decision-making in the development of internationalization strategy (Anderson \& Gatignon, 1986; Hill, Hwang, \& Kim, 1990; Agarwal \& Ramaswami, 1992). Therefore, this study will focus on the mode of market entry as key object of investigation which does also include the mode of market cultivation. For simplification of the research approach, no distinction will be made between initial mode of market entry and the potentially different mode of market cultivation at the time of the study.

\subsection{Resources and Dynamic Capabilities as Determinants of Market Entry Mode}

To explain the importance of considering the firm's individual characteristics in designing internationalization strategies, a closer look on its resources, competences and capabilities is required. The resource-based view (Wernerfelt, 1984; Prahalad \& Hamel, 1990; Barney, 1991; Grant, 1991) is a common theory that intends to explain performance differences between firms. The theory presumes that tangible and intangible assets of a firm are distributed asymmetrically as resources for the development of competencies, which, by way of varying manifestations, imply performance variations (Grant, 1991). If resources and competencies of a firm are valuable and rare, costly to imitate, and non-substitutable, a sustainable competitive advantage can be obtained (Barney, 1991). Resources are represented by tangible assets like financial resources or machinery. Competencies are intangible assets like patents or information, which are independent of individual persons, and capabilities of individuals like knowledge or skills (Hall, 1993). Competencies are required to deploy resources. Coming to corporate strategy, the resource based view recommends to "select a strategy which best exploits the firm's 
resources and capabilities relative to external opportunities" to maximise rents (Grant, 1991). One weakness of this approach is the fact that the framework is static and does not explain appropriately the competitive advantage of firms in changing environments (Priem \& Butler, 2001a, 2001b). As the renewable energy sector is a rapidly changing market, this theoretical defect has to be addressed by a more appropriate framework.

The dynamic capabilities view as an extension of the resource based view is better qualified as theory of strategy formulation in this market environment. The dynamic capabilities view was proposed by Teece et al. (1997) to enter into the question how firms can sustain competitive advantages in changing environments. As a major enhancement of the resource-based view the authors introduced dynamic capabilities as "the firm's ability to integrate, build, and reconfigure internal and external competences to address rapidly changing environments" (Teece et al., 1997). For strategy formulation this means that not only a given set of resources and competencies is required to gain competitive advantages but also the capability to develop and adapt these. Integrating the key messages of dynamic capabilities view and translating them into internationalization, a firm should gear its internationalization strategy in terms of market entry mode towards availability of resources, competencies and dynamic capabilities. The characteristics of corporate resources, competencies and capabilities determine the degree of complexity governing the mode of market entry which a company is capable to successfully implement (Müller-Stewens \& Lechner, 2002; Agarwal \& Ramaswami, 1992).

\subsection{Market Attractiveness and Market Barriers as Determinants of Market Entry Mode}

Internationalization strategy has not only to consider the firm's internal resources, competencies and capabilities; it also has to consider the characteristics of the target market. As briefly mentioned in Section 3.1, market attractiveness and market barriers are determining factors for the choice of the market entry mode and subsequent amendments during market cultivation. The two factors influence the appropriate level of resource commitment and level of control (Agarwal \& Ramaswami, 1992; Hill, Hwang, \& Kim, 1990; Malhotra, Agarwal, \& Ulgado, 2003). Based on the two dimensions Backhaus, Büschken, and Voeth (2003) defined four simplistic market types shown in Table 1.

Table 1. Market types

\begin{tabular}{ccc}
\hline & High market barriers & Low market barriers \\
\hline High market attractiveness & Promising market & Core market \\
Low market attractiveness & No-entry market & Occasional market \\
\hline
\end{tabular}

Source: Backhaus, Büschken, \& Voeth (2003, p. 124).

The illustration is static, but markets can evolve from one type into another. Important indicators for market attractiveness are e.g. market growth and market size (Kutschker \& Schmid, 2006; Meckl, 2010). Market barriers, which increase the market risk, can e.g. be tariff barriers (Kutschker \& Schmid, 2006) or competition (Scharrer, 2001). In markets with low market attractiveness or high market barriers firms tend to avoid or limit their risk of loss by choosing entry modes with low resource commitment (Hill, Hwang, \& Kim 1990), i.e. export or co-operations.

Looking at the four market types in Table 1 a firm is likely to forgo the market with low market attractiveness and high barriers or will use an entry mode with very low resource commitment, especially export. Core markets offer the chance for high market penetration by FDI with high resource commitment and high level of control (Backhaus, Büschken, \& Voeth, 2003; Meckl, 2010). Occasional markets do not bear high risks, though the low market attractiveness might not be substantial enough to break even with entry modes like FDI which tie up much capital. Thus, export or co-operations seem more appropriate to exploit the market potential opportunistically (Backhaus, Büschken, \& Voeth, 2003; Meck1, 2010). These resource light entry modes might also be preferable in promising markets. In these markets foreign firms are exposed to high risks due to the high market barriers. Export or co-operations limit the loss in case of a failure (Agarwal \& Ramaswami, 1992).

\subsection{The GAINS Approach as Link between Firm, Market and Internationalization Strategy}

Most research studies in international business use situational approaches and thus mostly bivariate research frameworks. For strategy research in the field of internationalization, which is far more complex than business development in a single, domestic market, the situational approach is not adequate (Strothe, 2006; Macharzina \& Engelhard, 1991). Examining the activities of an international firm, the complex environment with different 
markets has to be considered in a multivariate analysis of both the firm's and the markets' characteristics. A research approach which addresses the specific requirements of research of internationalization strategies is the "Gestalt Approach of International Business Strategies" (GAINS), which has been developed by Macharzina and Engelhard (1991). With the GAINS approach they have applied the configuration theory (Miles \& Snow, 1984; Miller \& Mintzberg, 1983; Miller, 1981, 1987; Miller \& Friesen, 1980, 1984) at an international level (Macharzina \& Engelhard, 1991). The configuration theory is a synthesis of the contingency theory and the system theory (Henselek, 1996) and tries to combine the strengths of both (Meckl, 2000). The configuration system is particularly suitable for research into foreign marketing, since, by way of its multidimensional research design, it can embrace the multifarious complexity of internationalization, with the interaction of corporate environment, corporate features and strategy (Meckl, 2000; Macharzina \& Engelhard, 1991).

In general, configurations are defined as "any multidimensional constellation of conceptually distinct characteristics that commonly occur together. Numerous dimensions of environments, industries, processes, practices, beliefs, and outcomes have been said to cluster into configurations, archetypes or "GESTALTS" (Meyer, Tsui, \& Hinings, 1993). The observed sets (Meckl, 2000), with typical configuration features, present a multidimensional, interdependent relationship which can change in due course (Scherer \& Beyer, 1998; Doty \& Glick, 1994; Miles \& Snow, 1984). Defining respective configurations is fundamental to establish a configuration system. Configurations represent groups of homogeneous companies with common characteristics in both internal and external operations (Miller \& Friesen, 1984; Miller, 1981).

The objective of the configuration theory is to find configurations which, by way of their main, coherent, external and internal features, belong to the "fit" category (Doty, Glick, \& Huber, 1993). The search for fit constellations is based on the assumption that these are particularly successful (Meckl, 2000; Roth, 1992; Khandwalla, 1973; Lawrence \& Lorsch, 1976). The complex configuration of a company, as a coordinated interaction of resources, competencies and capabilities, strategies, and environmental characteristics, can thus postulate a focal competitive advantage (Miller, 1999; Black \& Boal, 1994). This competitive advantage can bear a far greater potential than individually observed competence and resource profiles (Miller \& Whitney, 1999). Following Mintzberg's (1983) extended configuration hypothesis, four different types of configurations can be distinguished with respect to their level of fit. Table 2 illustrates the configurations based on fit of internal characteristics (consistency) and external characteristics (congruency).

Table 2. Types of configurations

\begin{tabular}{lcc}
\hline & Congruency $=$ Yes & Congruency $=$ No \\
\hline Consistency $=$ Yes & Gestalt & Consistent configuration \\
Consistency $=$ No & Congruent configuration & Misfit configuration \\
\hline
\end{tabular}

Source: Henselek (1996).

The FIT configuration as Gestalt, which shows a matching of both internal and external features, is the most successful configuration (Macharzina \& Wolf, 2012; Miles \& Snow, 1984). In contrast, a misfit configuration shows the lowest success (Miles \& Snow, 1984). If a simultaneous fit of internal and external features is not possible, the consistent configuration outmatches the congruent configuration (Ostroff \& Schmitt, 1993; Mintzberg, 1983; Khandwalla, 1973).

In terms of the GAINS approach Macharzina and Engelhard (1991) have developed exemplary configurations in the context of internationalization strategy. The configurations simultaneously consider internal variables like resources and (dynamic) capabilities as well as external variables. A detailed overview of potential internal and external features is given by Kutschker and Schmid (2006), Müller-Stewens and Lechner (1997) as well as Root (1987).

Analogous to the general definition of configuration theory, with the application to the international environment and search for suitable internationalisation strategies, the objective of the GAINS approach is to identify suitable configurations with matched corporate and environmental features. According to the underlying assumptions, a so-called "fit" is an indication that the potential for success of an internationalization strategy is relatively high (Macharzina \& Engelhard, 1991). Therefore, the selection of a fit strategy is critical for the success of internationalization. Due to the strengths of the GAINS approach for empirical research of internationalization strategies, especially in respect to the multivariate character, many other authors have availed themselves of the 
GAINS approach and applied it to international management research (Strothe, 2006; Meckl, 2000; Bufka, 1997; Roth, 1992; Roth, Schweiger, \& Morrison, 1991).

\section{Research Approach}

\subsection{Research Model}

The research approach is based on the previously described GAINS approach. Accordingly, the mode of market entry should be selected by considering the firm's internal resources, competencies and capabilities as well as the external target market characteristics. This can be summarized with the following two dimensions: market attractiveness and market barriers. Internal and external variables indirectly determine the success of internationalization via the selected market entry mode. The research approach is illustrated in Figure 1.

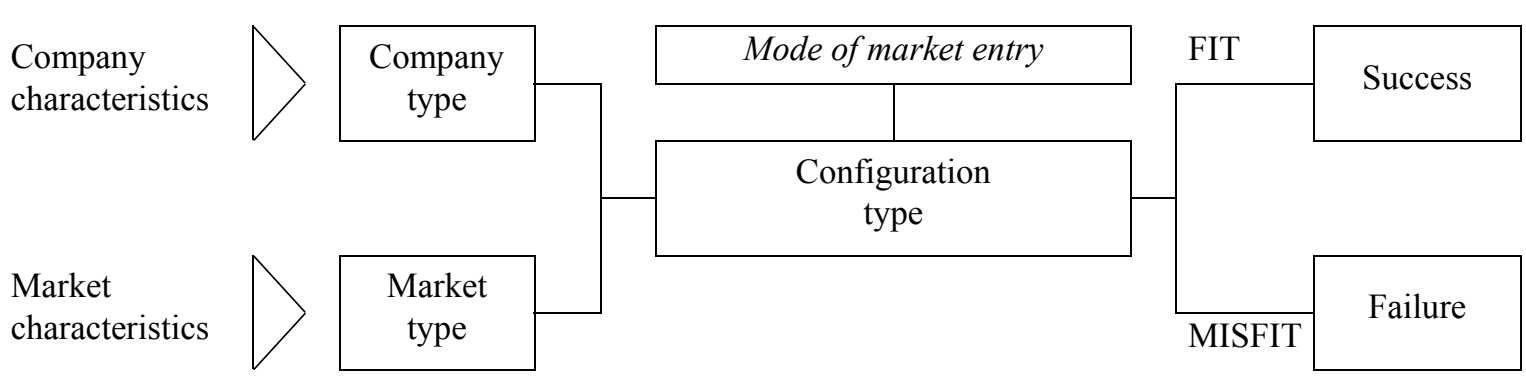

Figure 1. Simplified research model

(Source: own)

Based on firms' internal characteristics the companies will be clustered into ideal types of companies. Analogous, market types will be derived based on market characteristics. For derivation of hypotheses concerning the mode of market entry, export, co-operations, and subsidiaries (FDI) will be distinguished. The relation of company type and market type subsequently will decide the preferable configuration for internationalization. The configuration will focus on the mode of market cultivation and not on the potentially deviant entry mode. This seems reasonable as an ex-post analysis of market entry modes would require a retroactive evaluation of company characteristics, which would be inaccurate especially for the evaluation of intangible assets like competencies and capabilities. In addition, the measurement of internationalization success would be difficult to assess in the case of two or more modes of market entry and cultivation over time. The endogenous variable will be the success of foreign market cultivation for each specific market. This variable is necessary to check for a fit or misfit configuration.

\subsection{Definition of Hypotheses}

As shown in Section 3.1, each mode of market cultivation requires a different level of resource commitment, which includes both tangible and intangible resources. Marketing through a subsidiary is much more challenging and demanding for a company than marketing through export. Market entry or cultivation by export does not require a direct investment and incurs relatively few operating costs. In contrast, opening up a foreign subsidiary is capital-intensive and much more time-consuming, as regards to planning, launching, overseeing and controlling operations. The company must possess the necessary competencies, capabilities, and resources. Marketing through co-operation falls somewhere between export and subsidiary. Co-operations, such as alliances, as well as joint ventures, place fewer demands on the competence and resource facilities than the subsidiary, since, for this mode of marketing, the country-specific know-how, sales network, and contacts are available through co-operation partners and do not require in-house development (Madhok, 1998; Contractor \& Kundu, 1998; Pla-Barber, 2001). Contrary to export, co-operation requires heightened supervision and direction, since opportunistic behaviour of partners cannot be excluded (Ekeledo \& Sivakumar, 1998). This places greater demand on the competences and financial resources of a company. Additionally, the product quality needs to be raised, in order to be attractive for potential partners.

Based on the preceding explications, it may be assumed that companies with a weak competence, capability and resource profile (company type 1) will concentrate on market cultivation through export. Companies with better, albeit below-average, competence, capability and resource profile (company type 2) opt for co-operational 
marketing strategies. Companies with rather positive attributes (company type 3) and likewise those with very healthy competence, capability, and resource facilities (company type 4) select subsidiaries for their marketing strategy. The differentiation between the last two types seems useful to be able to distinguish between companies that are already international but do not yet have a long-standing record of market entries. The latter is the case when looking at company type four, a cluster for global players that feel as familiar in foreign markets as in their domestic market. Table 3 summarizes the ideal mode of market cultivation for each of the four company types.

Table 3. Company typologies

\begin{tabular}{cccc}
\hline Company Type 1 & Company Type 2 & Company Type 3 & Company Type 4 \\
\hline $\begin{array}{c}\text { National Newcomer } \\
\text { (export) }\end{array}$ & National Player & International Newcomer & Global Player \\
(co-operation) & (subsidiary) & (subsidiary) \\
\hline low & Degree of Resources, Competencies, and Capabilities & high \\
\hline
\end{tabular}

Source: own.

According to the GAINS approach, there is also an ideal mode of market entry for every foreign market, irrespective of the type of company. Determining factors embrace market attractiveness as well as market barriers involved in foreign marketing (Agarwal \& Ramaswami, 1992). In a growing sector such as the RE sector, market growth and market volume are determining factors for the market attractiveness. Growth is particularly important, since PV and wind power plants represent long term capital investment. Alternative investment as, e.g., the so-called re-powering in wind energy, until lately, only carried a limited market potential. Additionally, a RE market must attain a certain volume, since high growth with small market volume offers no satisfactory alternative investment. Market barriers, a further influencing factor, is - apart from general variables such as cultural distance and political stability — primarily determined by subsidy policies, since without these, the RE sector is not yet as competitive as conventional energy sources. Changes in subsidy policies could suddenly open up — or destroy—new markets. Especially in the RE sector, transparent policies are, with a view to planning certainty, a crucial factor influencing market risk.

The greater the cultural distance (Kogut \& Singh, 1988), the more intransparent the government policy (Williamson, 1979), and the more insecure the local competitive conditions the higher are the market barriers. In the case of high market barriers, companies are subject to a high risk of failure. This imposes a limitation or minimisation on resources invested in foreign market activity. This can be accomplished through export (Agarwal \& Ramaswami, 1992; Contractor \& Kundu, 1998). Vice-versa, i.e. in the case of low market risk, there is nothing to deter companies from transferring a high portion of competences and resources to the foreign market. Market potential generally leans towards marketing through subsidiaries, since these are best able to exploit the market potential (Erramilli et al., 1997; Ekeledo \& Sivakumar, 1998). In the case of low market potential, however, competence and resource transfer should be limited, according to the limited return on marketing abroad.

Depending on the specifications of both market risk and market potential, ideal and therefore potentially successful marketing modes can be determined. Export is recommended for markets with low market potential and low risks (market type 1), in order that these markets, despite their low market potential, may be tapped profitably using limited competences and resources, i.e. few opportunistic costs. In the case of high market potential, which nevertheless involves high risks (market type 2), co-operation should be cultivated to share the risk of loss and to limit the risks through collaborative use of competences and resources. The available market potential can thus be better exploited compared to export. Where market risk is low (market type 3), a high market potential can be tapped more effectively through a subsidiary, whereby the low market risk does not pose a threat to competences and resources. Market entry in markets representing high risks and low market potential (market type 4) is economically unviable. Therefore, market type 4 will not be considered in the further analysis. Figure 2 summarizes the market types. 


\begin{tabular}{|c|c|c|c|}
\hline \multirow{2}{*}{ 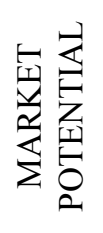 } & .0.0 & $\begin{array}{l}\text { Market Type } 2 \\
\text { (co-operation) }\end{array}$ & $\begin{array}{c}\text { Market Type } 3 \\
\text { (subsidiary) }\end{array}$ \\
\hline & 르 & $\begin{array}{c}\text { Market Type } 4 \\
\text { (No entry) }\end{array}$ & $\begin{array}{c}\text { Market Type } 1 \\
\text { (export) }\end{array}$ \\
\hline & & high & Low \\
\hline
\end{tabular}

Figure 2. Market typologies

(Source: own)

For companies operating in the RE sector, the most potentially successful internationalization strategies, depending on internal competence and resource facilities in certain market types, are of prime interest. For this purpose, as demonstrated in Figure 1, strategies in the sense of "fit" configurations are to be identified with a significant evidence for higher success than other configurations. In view of the huge differences in the competence and resource facilities of companies operating in the German RE sector, the search for company specific "fit" configurations takes on a special significance.

The first step in defining hypotheses is to validate the key assumption of the configuration theory, which postulates that the fit configuration as Gestalt, which shows both consistency and congruency, being most successful configuration (Macharzina \& Wolf, 2012; Miles \& Snow, 1984). This means that:

H1: Fit configurations are more successful than all other configurations.

H2: Fit configurations are more successful than light fit configurations.

H3: Fit configurations are more successful than consistent configurations.

H4: Fit configurations are more successful than congruent configurations.

H5: Fit configurations are more successful than misfit configurations.

FIT, CONSISTENT, CONGRUENT and MISFIT configurations have been explained previously in Section 3.5. LIGHT FIT configurations have been added as a fifth configuration to be able to reasonably account for company and market sets which could achieve a FIT configuration with the right mode of market entry but which chose a slightly less suitable mode of market entry. An example is a strong and experienced company type 4 which enters a market with high market potential and low risk. It could achieve a fit configuration by setting up a subsidiary. However, it chooses a co-operation or export. Both market and company allow for that mode of market entry, it is only the market potential which will not be fully exploited compared to a subsidiary. A LIGHT FIT configuration on the other hand can be clearly distinguished from MISFIT configurations, as these are configurations where both company and market do not allow for the selected mode of market entry. A MISFIT configuration would be a weak company type 1 that enters a market with low potential and high risk via FDI. For that reason is seems necessary to add LIGHT FIT configurations to be able to consider these sets.

Another key assumption of the underlying configuration theory is that consistent configurations show higher success than congruent configurations (Ostroff \& Schmitt, 1993; Mintzberg, 1983; Khandwalla, 1973). This leads to the following hypothesis:

H6: Consistent configurations are more successful than congruent configurations.

As explained, light fit configurations are not a perfect "fit" match, as market and company type allow for higher investment of resources and competencies. On the other hand it obviously is not a mismatch. Therefore it can be assumed that they are more successful than misfit configurations.

H7: Light fit configurations are more successful than misfit configurations.

Finally, misfit configurations are said to be the least successful constellation (Miles \& Snow, 1984):

H8: Misfit configurations show lower success than all other configurations.

The next step is to generate hypotheses corresponding to the market entry mode which the individual company should select, ideally according to its competence and resource profile and market type. Respective configuration hypotheses based on the GAINS approach will be established subsequently based on market types and company types. A company will clearly opt for the recommended market entry mode, whereby the competence and 
resource demands of the market are optimally met by the company type. If there is a correlation between Gestalt recommendations of companies and market types, with a view to selection of mode of market cultivation, a FIT configuration is achieved. This means:

H9: If the combination of company type and market type allows for a fit configuration, the company will select the respective mode of market entry.

If there is a deviation of the Gestalt recommendations of company and market type in respect to the selection of the market entry mode, then it is the case of a divergent configuration. Referring to Table 2, divergent constellations are either consistent or congruent configurations.

As consistent configurations are superior to congruent configurations (Ostroff \& Schmitt, 1993; Mintzberg, 1983; Khandwalla, 1973), a company will opt for consistent configurations, if a fit configuration is not obtainable. This leads to the following hypotheses:

H10: If the combination of company type and market type does not allow for a fit configuration, the company will select the required mode of market entry to achieve consistency.

If fit, congruency, and consistency are not given, the configuration is called misfit configuration. It can be assumed that companies will try to avoid misfit configurations, as this configuration is said to be the least successful type.

H11: Companies avoid misfit configurations.

\section{Empirical Examination of the Hypotheses}

\subsection{Operationalization of the Hypotheses}

\subsubsection{Company Types}

Analysis of resources, competencies and capabilities was performed with use of established, empirically validated indicators (Lierow, 2006). Table 4 shows an overview of the variables deployed.

Table 4. Company factors

\begin{tabular}{llll}
\hline No. & Competencies and Capabilities & No. & Resources \\
\hline C1 & Expansion and deployment of internationalization experience & R1 & Financial resources \\
C2 & Use of information sources & R2 & Perceived brand image \\
C3 & Organizational support for communication & R3 & Perceived product and service quality \\
C4 & Control and analysis of internationalization success & R4 & Access to latest technologies \\
C5 & Entrepreneurship & R5 & Product range \\
\hline
\end{tabular}

Source: own.

C1 The internationalization process can be improved with education in the field of internationalization, a prerequisite of which is individual empirical knowledge. Competences evolve through learning from success and failure and collective experience, which can be transferred to new internationalization processes. This reduces insecurity, thereby minimising the risk of failure, whereby marketing modes demanding higher-level resources and competences can be selected. This type of rationale corresponds to the Uppsala school of thought (Johanson \& Vahlne, 1977). This learning approach is reinforced by an active deployment of individual internationalization experience for the company in the process of internationalization by means of educational exchange and communication.

C2 Deployment of information sources likewise serves to minimise risks, since expansion of knowledge governing the internationalization process or foreign markets reduces insecurity and improves reaction skills (Burmann, 2002). In a dynamic international environment and especially for market entry to a new market, state-of-the-art information concerning the markets is indispensable (Craigh \& Douglas, 1996). As shown, this considerably affects the growing, state-subsidised photovoltaic and wind power markets. Knowledge culled through information sources should therefore be perceived as complementary to empirical knowledge.

C3 Dissemination of knowledge and integration within the company can be further improved by the organizational support of communication (Lierow, 2006). 
C4 Control and analysis of internationalization success subsequently serves as feedback for implemented internationalization strategies or sub-strategies, whereby experience and knowledge, with respect to relevant usage, can be evaluated and purposefully integrated (Lierow, 2006). This, too, contributes to appropriate decision-making with regard to internationalization procedure, by way of reducing insecurity. Due to the dynamics governing the international environment of the RE sector, with increasing global competition, it is moreover advantageous for the companies if existing knowledge can be combined in order to be able to react more flexibly to new challenges (Lierow, 2006).

C5 The ability and willingness to act and react in a flexible and innovative manner is subsumed under the competence Entrepreneurship. This competence also limits the risk of failure.

The second trait group comprises resources. They serve to realise company goals.

R1 Financial resources are an important element for the acquisition of inputs and also for the financing of internationalization procedures. The foundation of e.g. a production unit can prove foreign market entry to be extremely capital-intensive (Meckl, 2010). This is why financial resources are needed to offset bottlenecks arising from strategic options governing internationalization (Agarwal \& Ramaswami, 1992).

R2+R3 Perceived brand image, as well as product and service quality at home and abroad, can likewise influence the selection of international strategies. A good image and high product and service quality can enhance the success potential, which inversely implies reduced risk for competence and resource transfer in the context of internationalization. As already shown, German manufacturers operating in the photovoltaic and wind power industry were able to establish competitive advantages in the past, by way of their special quality, rendering these resources particularly significant.

R4 Closely connected to brand image and quality is the access to the latest technology, since innovative products carry a greater market potential than antiquated models. This bears considerable relevance for the two industrial sectors in question, since the technological development is racing ahead.

R5 A higher market potential is also yielded through a broad product range, from singular products to turnkey solutions, since in both PV and wind power segments, respective customer segments form an entire spectrum of demand, so that the entire market potential can be tapped.

In the operationalization of the variables, the deployed indicators were examined on a 7-point Likert scale. The turnover was yielded as an absolute value for the year 2008, whilst internationalization experience was expressed in terms of number of market entries. Since the company type was defined by 19 indicators, the information was condensed by means of a factor analysis (Appendix $1 \& 2$ ). By means of factor analysis of the 10 competence indicators the two factors, "Organisational degree of maturity of the company with regard to internationalization" (factor 1) and "Professionalism of the internationalization process" (factor 2) could be extracted. In the case of resources, 9 indicators were applied. Based on MSA values of below 0.5 the indicators "Revenues" and "Product range" were excluded from the factor analysis on account of inadequate suitability. Using the remaining indicators, the two factors "Product quality abroad" and "Product quality in Germany" could be extracted according to the Kaiser criterion. The indicator "Financial resources", due to its inadequate suitability for factor analysis, is included with the four extracted factors for the grouping of companies, since this, as strongly limiting factor, presents an important influencing variable for the selection of marketing mode.

The allocation of the companies to the four theoretically developed company typologies ensued according to the respective factor values and standardized turnover figures for the business year 2008 as shown in Table 5 .

Table 5. Degree of resources, competencies and capabilities per company typology

\begin{tabular}{cccc}
\hline $\begin{array}{c}\text { Company Type 1 } \\
\text { National Newcomer }\end{array}$ & $\begin{array}{c}\text { Company Type 2 } \\
\text { National Player }\end{array}$ & $\begin{array}{c}\text { Company Type 3 } \\
\text { International Newcomer }\end{array}$ & $\begin{array}{c}\text { Company Type 4 } \\
\text { Global Player }\end{array}$ \\
\hline $\begin{array}{c}\text { Max. 1 factor value above } \\
\text { median }\end{array}$ & 2 factor values above median & 3 factors values above median & $\begin{array}{c}\text { Min. } 4 \text { factor values above } \\
\text { median }\end{array}$ \\
\hline
\end{tabular}

Source: own.

\subsubsection{Market Types}

Market types are defined according to the two most influential factors: market potential and market risks. Market 
potential represents the mean market growth and market volume for the years 2007 and 2008. Respective data is available through a secondary survey of industrial sector reports (Fontaine et al., 2009; emerging energy research, 2009; World Wind Energy Association, 2009). Market risk is portrayed through the variables cultural distance, stability of competitive conditions and transparency of political decisions. The cultural distance (Hofstede, 1983) between Germany and the respective foreign market is calculated on the basis of the research findings of Hofstede (www.geert-hofstede.com/hofstede_dimensions.php) with use of the Kogut/Singh formula (Kogut \& Singh, 1988). For determination of competitive conditions the variables "Protection of Property Rights" and "Efficiency of Legal Framework" are applied. These are surveyed annually from the World Economic Forum. The equally-weighted country ratings were aggregated for the "competitive conditions" factor. The subsidy policy is analysed according to the variable "Transparency of policy making", which is likewise determined by the World Economic Forum. All country ratings were taken from the World Competitiveness Report 2008/2009 (Porter \& Schwab, 2008). The calculated country scores of the three variables, after normalisation, were summarised in the factor "Market risk". Depending on scale values above or below mean value of the two market dimensions each market was allocated to one of the four market types.

\subsubsection{Internationalization Success}

For evaluation of internationalization success, three empirically tested qualitative success indicators were employed (Lierow, 2006; Roth, Schweiger, \& Morrison, 1991) and adapted for evaluation at country level (Appendix 3). In each of the three indicators, which analyse the various dimensions of success of internationalization strategies, an estimate of relative success in the respective foreign market was yielded against the direct competitors. With use of factor analysis, the three variables were condensed to the factor "Relative success of internationalization" (Appendix 4).

\subsection{Data Sample}

As the number of German wind turbine manufacturers and German photovoltaic cell and module producers is rather small a total population sampling was applied. A standardized questionnaire as well as a link to an online version of the questionnaire was sent to the management board or senior directors of business development after initial phone contact. 23 German wind turbine manufacturers and 53 photovoltaic cell and module manufactures had been asked to participate in the survey. The survey period was three months. Out of the 33 submitted responses only 28 were complete and applicable. The 28 companies, 9 wind turbine manufacturers and 19 cell and module manufacturers, provided information on 207 market entries in 31 markets.

\subsection{Testing of Hypotheses}

Testing of the hypotheses is necessary for confirming the prognostic ability of the GAINS approach, thereby enabling the creation of concrete Gestalt recommendations for the RE sector. From the total of 207 market entries observed, 17 were located in market type 4 , which was excluded from the survey. The remaining sample comprises 190 market entries from 27 companies into 30 different markets. 18 companies belong to the PV sector, while nine companies are wind turbine manufacturers. With regard to the factor internationalization success, 127 reflect a complete data set with regard to all three success indicators, which justifies a sample unit of 127 for the testing of internationalization success.

Hypotheses $\mathrm{H} 1$ to $\mathrm{H} 8$ were tested with a one-way analysis of variance. The configuration type was defined as independent variable; relative success of internationalization was selected as dependent variable. Contrasts were defined to be able to compare the means of success of the five different configurations according to the hypotheses. Descriptive data analysis shows means differences across the five configurations. Although the Levene Statistic is not significant equal variances cannot be assumed as the sample sizes are quite small and both Welch and Brown-Forsythe are not significant. Therefore, equal variances are not assumed.

Table 6. Descriptives (relative success of internationalization)

\begin{tabular}{|c|c|c|c|c|c|c|c|c|}
\hline & \multirow[b]{2}{*}{$\mathrm{N}$} & \multirow[b]{2}{*}{ Mean } & \multirow[b]{2}{*}{$\begin{array}{c}\text { Std. } \\
\text { Deviation }\end{array}$} & \multirow[b]{2}{*}{ Std. Error } & \multicolumn{2}{|c|}{ 95\% Confidence Interval for Mean } & \multirow[b]{2}{*}{ Minimum } & \multirow[b]{2}{*}{ Maximum } \\
\hline & & & & & $\begin{array}{l}\text { Lower } \\
\text { Bound }\end{array}$ & Upper Bound & & \\
\hline FIT & 23 & 0.3698 & 0.84571 & 0.17634 & 0.0041 & 0.7355 & -0.93 & 1.72 \\
\hline LIGHT FIT & 63 & -0.0033 & 1.10535 & 0.13926 & -0.2817 & 0.2751 & -2.98 & 1.72 \\
\hline CONSISTENT & 19 & 0.2569 & 0.64271 & 0.14745 & -0.0529 & 0.5667 & -0.60 & 1.72 \\
\hline
\end{tabular}




\begin{tabular}{lllllllll}
\hline CONGRUENT & 19 & -0.3088 & 0.99570 & 0.22843 & -0.7887 & 0.1711 & -2.68 & 1.72 \\
MISFIT & 4 & -0.3809 & 1.04732 & 0.52366 & -2.0474 & 1.2856 & -1.77 & 0.58 \\
Total & 128 & 0.0452 & 0.99838 & 0.08824 & -0.1294 & 0.2198 & -2.98 & 1.72 \\
\hline
\end{tabular}

Table 7. Test of homogeneity of variances (relative success of internationalization)

\begin{tabular}{cccc}
\hline Levene Statistic & df1 & df2 & Sig. \\
\hline 2.042 & 4 & 123 & 0.093 \\
\hline
\end{tabular}

Table 8. Anova (relative success of internationalization)

\begin{tabular}{lrrrrr}
\hline & Sum of Squares & df & Mean Square & F & Sig. \\
\hline Between Groups & 6.530 & 4 & 1.633 & 1.673 & 0.161 \\
Within Groups & 120.057 & 123 & 0.976 & & \\
Total & 126.588 & 127 & & & \\
\hline
\end{tabular}

Table 9. Contrast coefficients

\begin{tabular}{crrrrr}
\hline & \multicolumn{5}{c}{ Selected internationalization configuration } \\
\cline { 2 - 6 } Contrast & FIT & LIGHT FIT & CONSISTENT & CONGRUENT & MISFIT \\
\hline 1 & 0.8 & -0.2 & -0.2 & -0.2 & 0.2 \\
2 & 1.0 & -1.0 & 0 & 0 & 0 \\
3 & 1.0 & 0 & -1.0 & -1.0 & 0 \\
4 & 1.0 & 0 & 0 & 0 & -1.0 \\
5 & 1.0 & 0 & 0 & -1.0 & 0 \\
7 & 0 & 0 & 1.0 & 0.2 & -0.8 \\
\hline
\end{tabular}

Table 10. Contrast tests

\begin{tabular}{|c|c|c|c|c|c|c|c|}
\hline & & Contrast & $\begin{array}{l}\text { Value of } \\
\text { Contrast }\end{array}$ & Std. Error & $\mathrm{t}$ & $\mathrm{df}$ & $\begin{array}{r}\text { Sig. } \\
\text { (2-tailed) }\end{array}$ \\
\hline \multirow{14}{*}{$\begin{array}{l}\text { Relative success of } \\
\text { internationalisation }\end{array}$} & \multirow{7}{*}{$\begin{array}{l}\text { Assume equal } \\
\text { variances }\end{array}$} & 1 & 0.3831 & 0.20409 & 1.877 & 123 & 0.063 \\
\hline & & 2 & 0.3731 & 0.24069 & 1.550 & 123 & 0.124 \\
\hline & & 3 & 0.1129 & 0.30629 & 0.369 & 123 & 0.713 \\
\hline & & 4 & 0.6786 & 0.30629 & 2.216 & 123 & 0.029 \\
\hline & & 5 & 0.7507 & 0.53522 & 1.403 & 123 & 0.163 \\
\hline & & 6 & 0.5657 & 0.32054 & 1.765 & 123 & 0.080 \\
\hline & & 7 & 0.3676 & 0.40324 & 0.912 & 123 & 0.364 \\
\hline & \multirow{7}{*}{$\begin{array}{l}\text { Does not assume } \\
\text { equal variances }\end{array}$} & 1 & 0.3831 & 0.18602 & 2.059 & 20.502 & 0.052 \\
\hline & & 2 & 0.3731 & 0.22470 & 1.661 & 50.964 & 0.103 \\
\hline & & 3 & 0.1129 & 0.22986 & 0.491 & 39.761 & 0.626 \\
\hline & & 4 & 0.6786 & 0.28858 & 2.352 & 35.524 & 0.024 \\
\hline & & 5 & 0.7507 & 0.55255 & 1.359 & 3.712 & 0.251 \\
\hline & & 6 & 0.5657 & 0.27188 & 2.081 & 30.781 & 0.046 \\
\hline & & 7 & 0.3676 & 0.42483 & 0.865 & 3.172 & 0.447 \\
\hline
\end{tabular}


To be able to draw conclusions on the hypotheses, the evaluation of the contrasts was processed (Table 10). As the p-value in the output is two-tailed while hypotheses H1-H6 are directed hypothesis, a p-value of 0.1 can be considered as significant. Accordingly, $\mathrm{H} 1$ can be confirmed as contrast 1 shows a two tailed significance of 0.052. $\mathrm{H} 2$ and $\mathrm{H} 3$ cannot be confirmed with a two tailed significance of 0.103 (contrast 2) and 0.626 (contrast 3), respectively. Therefore, fit configurations are more successful compared to all other configurations but the observed mean difference both to light fit and consistent configurations is not significant. However, it is significant for hypothesis $\mathrm{H} 4$, which shows a two-tailed p-value of 0.024 . Fit configurations show significantly higher internationalization success compared to congruent configurations. As the group size of misfit configuration is very small with a sample set of 4 market entries, hypothesis $\mathrm{H} 5$ has to be rejected due to insignificant $\mathrm{p}$-value. In contrast, the mean difference of success between consistent and congruent configurations is significant with a two-tailed p-value of 0.046. Therefore, hypothesis H6 can be confirmed. Hypothesis H7, again, has to be rejected due to small number of observed misfit configurations in the sample.

For analysis of hypotheses H9-H11 a one-sample t-test was applied. For each test, the null hypothesis assumed randomly chosen configurations. As the hypotheses do not require a complete data set in terms of success of internationalization, a sample of 190 market entries was available. For each observed market entry, the expected configuration was labelled with the value one while unexpected configurations were labelled with the value zero. As in several company-market combinations more than two configurations could be selected, the expectation value for randomly chosen configurations was calculated individually for each hypothesis (Appendix 5).

With a two-tailed p-value of 0.156 , hypothesis $\mathrm{H} 9$ cannot be confirmed. The observed mean value does not significantly differ from the expected value. That means that fit configurations are not preferred by companies. Hypothesis $\mathrm{H} 10$ assumed that if the combination of company type and market type does not allow for a fit configuration, the configuration of choice will be a consistent configuration. As the two-tailed p-value of 0.031 is significant, this hypothesis can be confirmed. Companies do prefer consistent configurations if fit configurations cannot be achieved. Finally, the test of hypothesis H11 shows a highly significant result which confirms the assumption that companies avoid misfit configurations. The results are presented in Appendix 6.

\subsection{Testing for Suitability of the Applied GAINS Model}

In order to test the suitability of the applied research model and the selected indicators for market and company characteristics, testing focused on whether the selected corporate and market features bore any significant influence on the mode of market entry. The multi-nominal logistic regression enables a respective empirical investigation of the 190 observed market entries (Table 11). In this analysis, the probability of the model chi-square of the model fitting information was highly significant, which shows that the model gives adequate predictions compared to the Intercept Only (Null model). Pearson Chi-Square cannot be interpreted as $66.7 \%$ of cells had zero frequencies. Test for multicollinearity of the independent variables is negative due to good Tolerance and VIF values (Appendix 7). Pseudo R-Square statistics show good accuracy. According to the Nagelkerke $\mathrm{R}^{2}, 44.2 \%$ of the variance with regard to the group classification can be explained by the seven variables (Table 10).

Table 11. Case processing summary

\begin{tabular}{lrcc}
\hline & & $\mathrm{N}$ & Marginal Percentage \\
\hline Mode of market entry & EXPORT & 99 & $52.1 \%$ \\
& CO-OPERATION & 28 & $14.7 \%$ \\
& SUBSIDIARY & 63 & $33.2 \%$ \\
Valid & 190 & $100.0 \%$ \\
Missing & 17 & \\
Total & 207 & \\
Subpopulation & $190^{\mathrm{a}}$ & \\
\hline
\end{tabular}

a. The dependent variable has only one value observed in 190 (100.0\%) subpopulations. 
Table 12. Test of the model

\begin{tabular}{|c|c|c|c|c|c|}
\hline \multicolumn{6}{|c|}{ Model Fitting Information } \\
\hline \multirow[b]{2}{*}{ Model } & \multicolumn{2}{|c|}{ Model Fitting Criteria } & \multicolumn{3}{|c|}{ Likelihood Ratio Tests } \\
\hline & \multicolumn{2}{|c|}{-2 Log Likelihood } & Chi-Square & df & Sig. \\
\hline Intercept Only & \multicolumn{2}{|c|}{375.397} & & & \multirow[b]{2}{*}{0.000} \\
\hline Final & \multicolumn{2}{|c|}{284.446} & 90.951 & 14 & \\
\hline \multicolumn{4}{|c|}{ Goodness-of-Fit } & \multicolumn{2}{|c|}{ Pseudo R-Square } \\
\hline & Chi-Square & df & Sig. & Cox and Snell & 0.380 \\
\hline Pearson & 350.751 & 364 & 0.682 & Nagelkerke & 0.442 \\
\hline Deviance & 284.446 & 364 & 0.999 & McFadden & 0.242 \\
\hline
\end{tabular}

The classification table (Table 13) shows an overall accuracy of $70.5 \%$ which is far better that the chance accuracy rate of $40.3 \%$. However, the model does not give better accuracies compared to the Null Model for the group "Co-operation" with only $17.9 \%$ of correctly predicted cases.

Table 13. Classification

\begin{tabular}{lccrc}
\hline & & \multicolumn{3}{c}{ Predicted } \\
\cline { 2 - 5 } Observed & EXPORT & CO-OPERATION & SUBSIDIARY \\
\hline EXPORT & 87 & 2 & 10 & $87.9 \%$ \\
CO-OPERATION & 19 & 5 & 4 & 42 \\
SUBSIDIARY & 21 & 0 & $66.7 \%$ & $29.5 \%$ \\
Overall Percentage & $66.8 \%$ & $3.7 \%$ & $70.5 \%$ \\
\hline
\end{tabular}

The independent variables product quality abroad, product quality in Germany, level of organizational maturity and professionalism of internationalization process, illustrate a significant to highly significant influence on the separation of groups in general (Table 14). The influence of the remaining three variables, in particular the standardized revenues, cannot be confirmed as valid for the whole population, due to a lack of significance. The lack of significance of both market variables is critical and will be discussed as limitation in the following chapter. The interpretation for the independent variables focuses on its ability to distinguish between pairs of market entry modes and the contribution which it makes to change the odds of being in one dependent variable group rather than in the other (Tables $15 \& 16$ ). An estimated multinomial logistic regression coefficient (B) with significant negative coefficient increases for high scale values of the variable the likelihood of being in the reference category. Parameters with positive coefficients and high scale value increase the likelihood of the response category. For all seven independent variables a high value represents a positive characteristic. E.g. a high scale value of quality abroad means a good perceived product quality in foreign markets. A high scale value of market risk indicates a rather low risk of market entry.

For the analysis of export versus subsidiary as reference group two parameters met the required significance level of $\mathrm{p}<0.05$. The variable "Perceived product quality abroad" had a highly significant relationship on the choice of market entry mode. A high product quality significantly increases the probability of export as market entry mode compared to the probability of a subsidiary. At first glance this tendency is not in line with the assumptions. A reciprocal relationship existed for the parameter "Professionalism of internationalization process". This variable showed a significant p-value. In this case a high level of professionalism increases the probability of the reference category subsidiary. This is well in line with the assumption that a high-level competence set is required to enter markets via FDI. Similar tendencies can be identified for the choice between co-operation and subsidiary as reference category. Again, good product quality increases the probability of a high 
level of competencies, in this case significantly described by the two variables "level of organizational maturity" and "professionalism of internationalization process", increases the probability of co-operations. The interpretation of the parameter estimates for export against the reference group co-operation is not reasonable due to $p$-values $>0.05$ among the independent variables.

Table 14. Likelihood ratio tests

\begin{tabular}{lcccc}
\hline & \multicolumn{2}{c}{ Model Fitting Criteria } & \multicolumn{2}{c}{ Likelihood Ratio Tests } \\
\cline { 2 - 5 } Effect & -2 Log Likelihood of Reduced & \multicolumn{2}{c}{ Sig. } \\
\hline Intercept & Model & Chi-Square & df & 0.000 \\
QUALITY_ABR & 302.761 & 18.315 & 2 & 0.000 \\
QUALITY_GER & 316.168 & 31.723 & 2 & 0.038 \\
ORG_MAT & 290.968 & 6.523 & 2 & 0.008 \\
PROF_INT & 294.069 & 9.623 & 2 & 0.000 \\
ZREVENUES & 306.582 & 22.136 & 2 & 0.810 \\
MARKET_RISK & 284.867 & 0.421 & 2 & 0.225 \\
MARKET_POT & 287.426 & 2.980 & 2 & 0.260 \\
\hline
\end{tabular}

The chi-square statistic is the difference in -2 log-likelihoods between the final model and a reduced model. The reduced model is formed by omitting an effect from the final model. The null hypothesis is that all parameters of that effect are 0 .

Although the overall model shows a good fit and four out of the seven independent variables have a significant or highly significant relation to the category selection, the fact that the two market variables do not have any significant relationship to the probability of market entry mode is critical and needs to be discussed.

Table 15. Parameter estimates with reference category co-operation

\begin{tabular}{|c|c|c|c|c|c|c|c|c|c|}
\hline \multirow{2}{*}{\multicolumn{2}{|c|}{ Mode of market entry }} & \multirow{3}{*}{$\frac{\mathrm{B}}{1.019}$} & \multirow{3}{*}{$\begin{array}{r}\text { Std. Error } \\
0.291\end{array}$} & \multirow{3}{*}{$\begin{array}{r}\text { Wald } \\
12.307\end{array}$} & \multirow{3}{*}{$\frac{\mathrm{df}}{1}$} & \multirow{3}{*}{$\begin{array}{l}\text { Sig. } \\
0.000\end{array}$} & \multirow{3}{*}{$\operatorname{Exp}(B)$} & \multicolumn{2}{|c|}{$95 \%$ Confidence Interval for $\operatorname{Exp}(\mathrm{B})$} \\
\hline & & & & & & & & \multirow[t]{2}{*}{ Lower Bound } & \multirow[t]{2}{*}{ Upper Bound } \\
\hline EXPORT & Intercept & & & & & & & & \\
\hline & QUALITY_ABR & 0.572 & 0.346 & 2.726 & 1 & 0.099 & 1.772 & 0.898 & 3.494 \\
\hline & QUALITY_GER & -0.318 & 0.272 & 1.360 & 1 & 0.244 & 0.728 & 0.427 & 1.241 \\
\hline & ORG_MAT & 0.511 & 0.269 & 3.602 & 1 & 0.058 & 1.667 & 0.983 & 2.825 \\
\hline & PROF_INT & -0.584 & 0.337 & 3.000 & 1 & 0.083 & 0.558 & 0.288 & 1.080 \\
\hline & ZREVENUES & -0.004 & 0.387 & 0.000 & 1 & 0.991 & 0.996 & 0.467 & 2.125 \\
\hline & MARKET_RISK & 0.315 & 0.462 & 0.464 & 1 & 0.496 & 1.370 & 0.554 & 3.391 \\
\hline & MARKET_POT & -0.055 & 0.305 & 0.033 & 1 & 0.857 & 0.947 & 0.521 & 1.719 \\
\hline \multirow[t]{8}{*}{ SUBSIDIARY } & Intercept & -0.128 & 0.401 & 0.103 & 1 & 0.749 & & & \\
\hline & QUALITY_ABR & -1.060 & 0.358 & 8.761 & 1 & 0.003 & 0.346 & 0.172 & 0.699 \\
\hline & QUALITY_GER & -0.798 & 0.332 & 5.790 & 1 & 0.016 & 0.450 & 0.235 & 0.862 \\
\hline & ORG_MAT & 1.005 & 0.364 & 7.615 & 1 & 0.006 & 2.732 & 1.338 & 5.580 \\
\hline & PROF_INT & 1.105 & 0.493 & 5.033 & 1 & 0.025 & 3.021 & 1.150 & 7.935 \\
\hline & ZREVENUES & 0.160 & 0.371 & 0.187 & 1 & 0.666 & 1.174 & 0.568 & 2.428 \\
\hline & MARKET_RISK & 0.843 & 0.522 & 2.603 & 1 & 0.107 & 2.322 & 0.834 & 6.464 \\
\hline & MARKET_POT & 0.363 & 0.335 & 1.177 & 1 & 0.278 & 1.438 & 0.746 & 2.774 \\
\hline
\end{tabular}

a. The reference category is: CO-OPERATION. 
Table 16. Parameter estimates with reference category subsidiary

\begin{tabular}{|c|c|c|c|c|c|c|c|c|c|}
\hline \multirow{2}{*}{\multicolumn{2}{|c|}{ Mode of market entry ${ }^{a}$}} & \multirow{3}{*}{$\begin{array}{c}\mathrm{B} \\
1.148\end{array}$} & \multirow{3}{*}{$\begin{array}{c}\text { Std. Error } \\
0.355\end{array}$} & \multirow{3}{*}{$\begin{array}{l}\text { Wald } \\
10.451\end{array}$} & \multirow{3}{*}{$\frac{\mathrm{df}}{1}$} & \multirow{3}{*}{$\begin{array}{l}\text { Sig. } \\
0.001\end{array}$} & \multirow{3}{*}{$\operatorname{Exp}(B)$} & \multicolumn{2}{|c|}{$95 \%$ Confidence Interval for $\operatorname{Exp}(B)$} \\
\hline & & & & & & & & \multirow[t]{2}{*}{ Lower Bound } & \multirow[t]{2}{*}{ Upper Bound } \\
\hline EXPORT & Intercept & & & & & & & & \\
\hline & QUALITY_ABR & 1.632 & 0.340 & 23.035 & 1 & 0.000 & 5.114 & 2.626 & 9.959 \\
\hline & QUALITY_GER & 0.480 & 0.264 & 3.306 & 1 & 0.069 & 1.617 & 0.963 & 2.713 \\
\hline & ORG_MAT & -0.494 & 0.359 & 1.899 & 1 & 0.168 & 0.610 & 0.302 & 1.232 \\
\hline & PROF_INT & -1.689 & 0.430 & 15.437 & 1 & 0.000 & 0.185 & 0.079 & 0.429 \\
\hline & ZREVENUES & -0.164 & 0.279 & 0.348 & 1 & 0.555 & 0.848 & 0.491 & 1.465 \\
\hline & MARKET_RISK & -0.528 & 0.402 & 1.724 & 1 & 0.189 & 0.590 & 0.268 & 1.297 \\
\hline & MARKET_POT & -0.418 & 0.257 & 2.644 & 1 & 0.104 & 0.658 & 0.397 & 1.090 \\
\hline \multirow[t]{8}{*}{ CO-OPERATION } & Intercept & 0.128 & 0.401 & 0.103 & 1 & 0.749 & & & \\
\hline & QUALITY_ABR & 1.060 & 0.358 & 8.761 & 1 & 0.003 & 2.886 & 1.431 & 5.823 \\
\hline & QUALITY_GER & 0.798 & 0.332 & 5.790 & 1 & 0.016 & 2.221 & 1.160 & 4.253 \\
\hline & ORG_MAT & -1.005 & 0.364 & 7.615 & 1 & 0.006 & 0.366 & 0.179 & 0.747 \\
\hline & PROF_INT & -1.105 & 0.493 & 5.033 & 1 & 0.025 & 0.331 & 0.126 & 0.870 \\
\hline & ZREVENUES & -0.160 & 0.371 & 0.187 & 1 & 0.666 & 0.852 & 0.412 & 1.762 \\
\hline & MARKET_RISK & -0.843 & 0.522 & 2.603 & 1 & 0.107 & 0.431 & 0.155 & 1.198 \\
\hline & MARKET_POT & -0.363 & 0.335 & 1.177 & 1 & 0.278 & 0.695 & 0.361 & 1.341 \\
\hline
\end{tabular}

a. The reference category is: SUBSIDIARY.

\section{Results and Discussion}

The objective of this study was, by means of the GAINS approach, to identify pointers for successful internationalization strategies in the RE sector, so that Gestalt recommendations for further internationalization of this sector could be established. The basic assumption of the GAINS approach and the configuration theory in general could be confirmed. First, FIT configurations showed higher relative internationalization success than every other configuration. The mean differences, however, were not significant for all pair-wise configuration comparisons. Yet, significant differences could be verified for FIT configurations compared to all other configurations as well as for FIT configurations compared to congruent configurations. Furthermore, the assumption of the configuration theory that consistent configurations being more successful than congruent configurations could be confirmed significantly as well. Finally, MISFIT configurations were identified as being significantly less successful than all other configurations. These findings clearly show that, whenever possible, companies should strive for the market entry mode that constitutes a FIT configuration. If a FIT configuration is not realisable due to market-company-characteristics, a consistent configuration should be chosen.

As the results show that the choice of the right mode market entry configuration increases the relative success of internationalization, it is a logical deduction that companies do try to achieve the most successful configuration by an appropriate market entry mode. Hypotheses H9-H11 were formulated to validate this assumption. Surprisingly, FIT configurations are not preferred significantly compared to other configurations. Subsequently, hypothesis $\mathrm{H} 9$ has to be rejected. This shows that companies in the renewable energies sector could have yielded higher returns on foreign activities by choosing FIT configurations. Many companies obviously missed market opportunities. Yet, the situation appears to be better in cases, when companies did not have the chance to achieve a FIT configuration but to enter into a consistent configuration. The number of consistent configurations significantly exceeded the expectancy value for the null hypotheses that the number of available configurations is distributed equally. Thus, hypothesis H10 could be confirmed. In addition, companies significantly tried to avoid MISFIT configurations, which proved hypothesis H11.

Finally, the fit of the applied model was tested with a multi-nominal regression model. Although the model itself showed a good accuracy, three results have to be addressed. Firstly, an interesting and unexpected result of the research is that high product quality at home and abroad increases the probability of export or co-operation 
compared to subsidiaries. A reverse effect was expected. One possible explanation for this result is that the German RE sector used to enjoyed a worldwide surplus of demand. In this seller's market a high product quality, until lately, represented a comparative competitive advantage: products could be introduced successfully to the respective markets via export as good product offers always met demand. Subsequently, there was no need to enter markets via complex FDI. Companies were able to spend resources and competencies on the exploitation of additional export markets in short time. It is to be expected, however, that for many markets and enterprises, export by itself will no longer suffice for successful and sustainable internationalization. Especially in the PV market there was little evidence of direct end-consumer access and, in the light of the excess of supply, subsidiaries are taking on a special significance. Only through local market presence end-user relations can be cultivated and sales volumes be secured. Long-term bulk-purchasing agreements with wholesalers and project developers will become increasingly more difficult to close, due to the shortfall. Doing business with functional intermediaries, involving additional wholesale margins, against a background of falling module prices, is not an attractive economic venture. Since, in the wind power plant manufacturers already keep closer contact to end-consumers, these statements can only be applied conditionally. Yet, as competition increases in the wind sector as well, customer relations will become more important. Thus, the recommendation to develop own local market presence can be applied to the wind power industry as well.

Second, it is important to mention that both independent market variables had no significant relationship to the probability of any of the three analysed market entry modes. Although the logistic regression coefficients indicate that the assumed influence on the market entry mode is valid, no empirical evidence is available. This raises two questions: A) are the selected indicators appropriate, or B) does market environment have an impact on mode of market entry? As the influence of market factors on choice of market entry mode was proven by various empirical studies (Morschett, Schramm-Klein, \& Swoboda, 2010), it seems likely that the selected indicators were not selected appropriately to describe the relevant market characteristics. However, if market characteristics do have an impact on mode of market entry, it is astonishing that many of the hypotheses could be proven despite statistically irrelevant market indicators. Therefore another question is, if the company characteristics described by resources, competencies and capabilities have a far bigger influence of the mode of market entry selection and the firm's internationalization success than market factors. The present study is not able to answer this question which is why the accuracy of the GAINS model itself has to be challenged. In the next step, a different operationalization of market variables could be applied. As the evaluation of market characteristics does not require primary research, the testing of another model with different market variables is feasible using the same set of company data. This would be an interesting subject to future research.

Finally, financial resources, indicated by standardized revenues, had no significant relationship to the probability of a market entry mode as well. As financial resources are a limiting factor for expansion strategies, a different indicator, e.g. free cash flow, might be more appropriate. This business ratio, however, is typically only available from listed companies. Interviews with managers of private companies in a preliminary study clearly showed that this sensible data would not be disclosed for the research study. In order to get a more suitable indicator the focus on listed renewable energy companies on a worldwide basis seems to be necessary to be able to obtain a sufficient sample size. The broadening of the sample population to foreign companies would also be an option in order to try to strengthen the obtained results as some relationships could not be validated significantly. A larger sample size might improve the explanatory power of the results.

Another limitation of the study is the intentional simplification of the market entry decision by limiting the focus of research to the mode of market entry and the market selection. As a next step, the consideration of entry timing and change of market entry mode over time in the research model would be another interesting approach.

The present study may therefore be perceived as a first step in a comprehensive scientific research into the RE sector within the scope of international management research. Since both PV and wind power sectors will become economically more significant in the foreseeable future, attaining grid parity and therefore independence from state subsidies, further insights into these two sectors would be eligible and meaningful.

\section{Acknowledgements}

The authors would like to acknowledge Sebastian Olbert for providing deep insights into the renewable energy market and Torsten Strehle for supporting the survey period with constructive criticism. Special thanks go to Ryan Graham for his helpful comments on a previous draft of this paper. Furthermore, the authors deeply thank all participating companies for the interest in and support of this research project. This publication was funded by the German Research Foundation (DFG) and the University of Bayreuth in the funding programme Open Access Publishing. 


\section{References}

Agarwal, S., \& Ramaswami, S. N. (1992). Choice of Foreign Market Entry Mode: Impact of Ownership, Location and Internalization Factors. Journal of International Business Studies, 23(1), 1-27. http://dx.doi.org/10.1057/palgrave.jibs. 8490257

Anderson, E., \& Gatignon, H., (1986). Modes of Entry: A Transactions Cost Analysis and Propositions. Journal of International Business Studies, 17(3), 1-26. http://dx.doi.org/10.1057/palgrave.jibs.8490432

Backhaus, K., Büschken, J., \& Voeth, M. (2003). Internationales Marketing (5th ed.). Stuttgart.

Barney, J. (1991). Firm Resources and Sustained Competitive Advantage. Journal of Management, 17(1), 99120. http://dx.doi.org/10.1177/014920639101700108

Black, J. A., \& Boal, K. (1994). Strategic Resources: Traits, Configurations and Paths to Sustainable Competitive Advantage. Strategic Management Journal, 15, Summer Issue, 131-148. http://dx.doi.org/10.1002/smj.4250151009

Buckley, P. J., \& Casson, M. (2002). The Future of the Multinational Enterprise. Palgrave Macmillan.

Bufka, J. (1997). Auslandsgesellschaften internationaler Dienstleistungsgesellschaften. Koordination-Kontext--Erfolg. Wiesbaden: Gabler Verlag. http://dx.doi.org/10.1007/978-3-322-84489-7

Burmann, C. (2002). Strategische Flexibilität und Strategiewechsel als Determinanten des Unternehmenswertes. Wiesbaden: DUV. http://dx.doi.org/10.1057/9780230371798

Calvet, A. L. (1981). A synthesis of foreign direct investment theories and theories of the multinational firm. Journal of International Business Studies, 12(1), 43-59. http://dx.doi.org/10.1057/palgrave.jibs.8490570

Contractor, F., \& Kundu, S. (1998). Franchising versus company-run operations: Modal choice in the global hotel sector. Journal of International Marketing, 6(2), 28-53.

Craigh, C. S., \& Douglas, S. P. (1996). Developing Strategies for Global Markets: An Evolutionary Perspective. Columbia Journal of World Business, 31(1), 70-81. http://dx.doi.org/10.1016/s0022-5428(96)90008-3

Doty, D. H., \& Glick, W. H. (1994). Typologies as a Unique Form of Theory Building: Toward Improved Understanding and Modeling. Academy of Management Review, 19(2), 230-251. http://dx.doi.org/10.5465/AMR.1994.9410210748

Doty, D. H., Glick, W. H., \& Huber, G. (1993). Fit, Equifinality, and Organizational Effectiveness: A Test of Two Configurational Theories. Academy of Management Journal, 36(6), 1196-1250. http://dx.doi.org/10.2307/256810

Ekeledo, I., \& Sivakumar, K. (1998). Foreign market entry mode choice of service firms: A contingency perspective. Journal of the Academy of Marketing Science, 26(4), 274-292. http://dx.doi.org/10.1177/0092070398264002

Emerging Energy Research. (2009). Global Wind Turbine Markets and Strategies, 2009-2020. Emerging Energy Research, Cambridge.

Erramilli, K., Agarwal, S., \& Kim, S.-S. (1997). Are firm-specific advantages location-specific too? Journal of International Business Studies, 28(4), 735-757. http://dx.doi.org/10.1057/palgrave.jibs.8490117

Fontaine, B., Fraile, D., Latour, M., Lenoir, S., Philbin, P., \& Thomas, D. (2009). Global market outlook for photovoltaics until 2013. European Photovoltaic Industry Association. Brussels.

Geert Hofstede ${ }^{\mathrm{TM}}$ Cultural Dimensions. Retrieved from http://geert-hofstede.com/dimensions.html

Grant, R. M. (1991). The Resource-Based Theory of Competitive Advantage: Implications for Strategy Formulation. California Management Review, 33(3), 114-135. http://dx.doi.org/10.2307/41166664

Hall, R. (1993). A Framework Linking Intangible Resources and Capabilities to Sustainable Competitive Advantage. Strategic Management Journal, 14(8), 607-618. http://dx.doi.org/10.1002/smj.4250140804

Henselek, H. F. (1996). Das Management von Unternehmenskonfigurationen. Wiesbaden: DUV. http://dx.doi.org/10.1007/978-3-322-97719-9

Hill, C., \& Kim, W. C. (1998). Searching for a dynamic theory of the multinational enterprise: A transaction cost model. Strategic Management Journal, 9(S1), 93-104. http://dx.doi.org/10.1002/smj.4250090710

Hill, C., Hwang, P., \& Kim, W. C. (1990). An eclectic theory of the choice of international entry mode. Strategic Management Journal, 11(2), 117-128. http://dx.doi.org/10.1002/smj.4250110204 
Hofstede, G. (1983). National Cultures in Four Dimensions. International Studies of Management \& Organization, 13(1/2), 46-74.

Jakopin, N. M. (2006). Einflussfaktoren des Internationalisierungserfolgs von Mobilfunknetzbetreibern. Wiesbaden: Gabler.

Johanson, J., \& Vahlne, J.-E. (1977). The Internationalization Process of the Firm-A Model of Knowledge Development and Increasing Foreign Market Commitments. Journal of International Business Studies, 8(1), 23-32. http://dx.doi.org/10.1057/palgrave.jibs.8490676

Khandwalla, P. N. (1973). Viable and Effective Organizational Designs of Firms. Academy of Management Journal, 16(3), 481-495. http://dx.doi.org/10.2307/255008

Kogut, B., \& Singh, H. (1998). The effect of national culture on the choice of entry mode. Journal of International Business Studies, 19(3), 411-432. http://dx.doi.org/10.1057/palgrave.jibs.8490394

Kotler, P. (1988). Marketing Management: Analysis, Planning, Implementation, and Control. Prentice Hall College Div.

Krohn, S., Morthorst, P.-E., \& Awerbuch, S. (2009). The Economics of Wind Energy. Soren Krohn, Denmark.

Kutschker, M., \& Schmid, S. (2006). Internationales Management (5th ed.). Munich.

Lawrence, P. R., \& Lorsch, J. W. (1976). Organization and Environment: Managing Differentiation and Integration. Boston: Harvard Business School Press.

Lierow, M. A. (2006). Competence-Building und Internationalisierungserfolg. Wiesbaden: DUV.

Lynch, R. (2009). Strategic Management (5th ed.). Harlow: Prentice Hall.

Macharzina, K., \& Engelhard, J. (1991). Paradigm Shift in International Business Research: From Partist and Eclectic Approaches to the GAINS Paradigm. Management International Review, 31, Special Issue, 23-43.

Macharzina, K., \& Wolf, J. (2012). Unternehmensführung (8th ed.). Wiesbaden: Springer Gabler. http://dx.doi.org/10.1007/978-3-8349-3840-4

Madhok, A. (1998). The nature of multinational firm boundaries: Transaction costs, firm capabilities and foreign market entry mode. International Business Review, 7(3), 259-290. http://dx.doi.org/10.1016/S0969-5931(98)00009-2

Malhotra, N. K., Agarwal, J., \& Ulgado, F. M. (2003). Internationalization and entry modes: a multitheoretical framework and research propositions. Journal of International Marketing, 1(1), 1-31. http://dx.doi.org/10.1509/jimk.11.4.1.20144

Meckl, R. (2000). Controlling im Internationalen Unternehmen. München: Vahlen.

Meckl, R. (2010). Internationales Management (2nd ed.). München: Vahlen.

Meyer, A., Tsui, A., \& Hinings, C. (1993). Configurational Approaches to Organizational Analysis. Academy of Management Journal, 36(6), 1175-1195. http://dx.doi.org/10.2307/256809

Miles, R. E., \& Snow, C. C. (1984). Fit, Failure and the Hall of Fame. California Management Review, 26(3), 10-28. http://dx.doi.org/10.2307/41165078

Miller, D. (1981). Toward a New Contingency Approach: the Search for Organizational Gestalts. Journal of Management Studies, 18(1), 1-26. http://dx.doi.org/10.1111/j.1467-6486.1981.tb00088.x

Miller, D. (1987). The Genesis of Configurations. Academy of Management Review, 12(4), 686-701. http://dx.doi.org/10.5465/AMR.1987.4306720

Miller, D. (1999). Notes on the Study of Configuration. Management International Review, 39, Special Issue, 27-39.

Miller, D., \& Friesen, P. H. (1980). Archetypes of Organizational Transition. Administrative Science Quarterly, 25(2), 268-299. http://dx.doi.org/10.2307/2392455

Miller, D., \& Friesen, P. H. (1984). Organizations: A Quantum View. Englewood Cliffs: Prentice-Hall.

Miller, D., \& Mintzberg, H. (1983). The Case for Configuration. In G. Morgan (Ed.), Beyond Method-Strategies for Social Research (pp. 57-73). Beverly Hills, London, New Delhi.

Miller, D., \& Whitney, J. O. (1999). Beyond Strategy: Configuration as a Pillar of Competitive Advantage. Business Horizon, 42(3), 5-17. http://dx.doi.org/10.1016/S0007-6813(99)80016-0 
Mintzberg, H. (1993). Structure in Fives: Designing Effective Organizations. Prentice Hall.

Molly, J. P. (2009). Status der Windenergienutzung in Deutschland. DEWI GmbH, Wilhelmshaven.

Morschett, D., Schramm-Klein, H., \& Swoboda, B. (2010). Decades of research on market entry modes: What do we really know about external antecedents of entry mode choice? Journal of International Management, 16(1), 60-77. http://dx.doi.org/10.1016/j.intman.2009.09.002

Morschett, D., Swoboda, B., \& Schramm-Klein, H. (2008). Einflussfaktoren auf die Wahl einer Markteintrittsstrategie-eine meta-analytische Untersuchung der Entscheidung zwischen Tochtergesellschaft und Kooperation. Zeitschrift für Betriebswirtschaft, 78(5), 509-551. http://dx.doi.org/10.1007/s11573-008-0031-1

Mrusek, K. (2010, January 18). Das Ende der Traumrenditen auf dem Dach. Frankfurter Allgemeine Zeitung.

Müller-Stewens, G., \& Lechner, C. (1997). Unternehmensindividuelle und gastlandbezogene Einflussfaktoren der Markteintrittsform. In K. Macharzina \& M.-J. Oesterle (Eds.), Handbuch Internationales Management (pp. 231-252). Wiesbaden: Gabler. http://dx.doi.org/10.1007/978-3-322-96463-2_11

Murphy, M., Stratmann, K., \& Weishaupt, G. (2010, January 14). Minister Röttgen setzt Solarbranche zu. Handelsblatt.

Ostroff, C., \& Schmitt, N. (1993). Configurations of Organizational Effectiveness and Efficiency. Academy of Management Journal, 36(6), 1345-1361. http://dx.doi.org/10.2307/256814

Pla-Barber, J. (2001). The internalisation of foreign distribution and production activities- $\mathrm{New}$ empirical evidence from Spain. International Business Review, 10(4), 455-474. http://dx.doi.org/10.1016/S0969-5931(01)00026-9

Porter, M. E. (1986). Competition in Global Industries. Boston: Harvard Business Press.

Porter, M. E., \& Schwab, K. (2009). The Global Competitiveness Report 2008-2009. World Economic Forum, Geneva.

Prahalad, H., \& Hamel, G. (1999). The Core Competence of the Corporation. Harvard Business Review, 68(3), 79-91. http://dx.doi.org/10.1016/B978-0-7506-7223-8.50003-4

Priem, R. L., \& Butler, J. E. (2001a). Is the Resource-based "View" a Useful Perspective for Strategic Management Research? Academy of Management Review, 26(1), 22-40. http://dx.doi.org/10.5465/AMR.2001.4011938

Priem, R. L., \& Butler, J. E. (2001b). Tautology in the resource-based view and the implications of externally determined resource value: further comments. Academy of Management Review, 26(1), 57-66. http://dx.doi.org/10.5465/AMR.2001.4011946

Pues, C. (1994). Markterschließungsstrategien bundesdeutscher Unternehmen in Osteuropa. Vienna: Wiss. Ges. für Marketing u. Unternehmensführung.

Pullen, A., Qiao, L., \& Sawyer, S. (2008). Global Wind 2008 Report. Global Wind Energy Council, Brussels.

Root, F. R. (1987). Entry Strategies for International Markets. Lexington.

Roth, K. (1992). International Configuration and Coordination Archetypes for Medium-Sized Firms in Global Industries. Journal of International Business Studies, 23(3), 533-549. http://dx.doi.org/10.1057/palgrave.jibs.8490278

Roth, K., Schweiger, D. M., \& Morrison, A. J. (1991). Global Strategy Implementation at the Business Unit Level: Operational Capabilities and Administrative Mechanisms. Journal of International Business Studies, 22(3), 369-402. http://dx.doi.org/10.1057/palgrave.jibs.8490307

Scharrer, J. (2001). Internationalisierung und Länderselektion. Eine empirische Analyse mittelständischer Unternehmen in Bayern. Munich: VVF.

Scherer, A. G., \& Beyer, R. (1998). Der Konfigurationsansatz im Strategischen Management-Rekonstruktion und Kritik. Die Betriebswirtschaft, 58(3), 332-347.

Strothe, D. (2006). Identifikation und Bewertung der Konfigurationen internationaler Marktein- und Marktaustrittsentscheidungen junger Technologieunternehmen. Frankfurt: Lang.

Teece, D. J., Pisano, G., \& Shuen, A. (1997). Dynamic Capabilities and Strategic Management. Strategic Management Journal, 18(7), 509-533. http://dx.doi.org/10.1142/9789812834478_0002 
Vernon, R. (1983). Organizational and institutional responses to international risk. In Richard J. H. (Ed.), Managing International Risk (pp. 191-216). Cambridge University Press. http://dx.doi.org/10.1017/CBO9780511664601.011

Welge, M. K., \& Holtbrügge, D. (2006). Internationales Management (4th ed.). Stuttgart.

Wernerfelt, B. (1984). A Resource-Based View of the Firm. Strategic Management Journal, 5(2), 171-180. http://dx.doi.org/10.1002/smj.4250050207

Williamson, O. E. (1979). Transaction-cost Economics: The Governance of Contractual Relations. Journal of Law and Economics, 22(2), 233-261. http://dx.doi.org/10.1086/466942

World Wind Energy Association. (2009). World Wind Energy Report 2008. World Wind Energy Association, Bonn.

Zervos, A., \& Kjaer, C (2008). Pure Power. Wind Energy Scenarios up to 2030. European Wind Energy Association, Brussels.

\section{Appendix}

App.1 Factor analysis of the specific resource variables

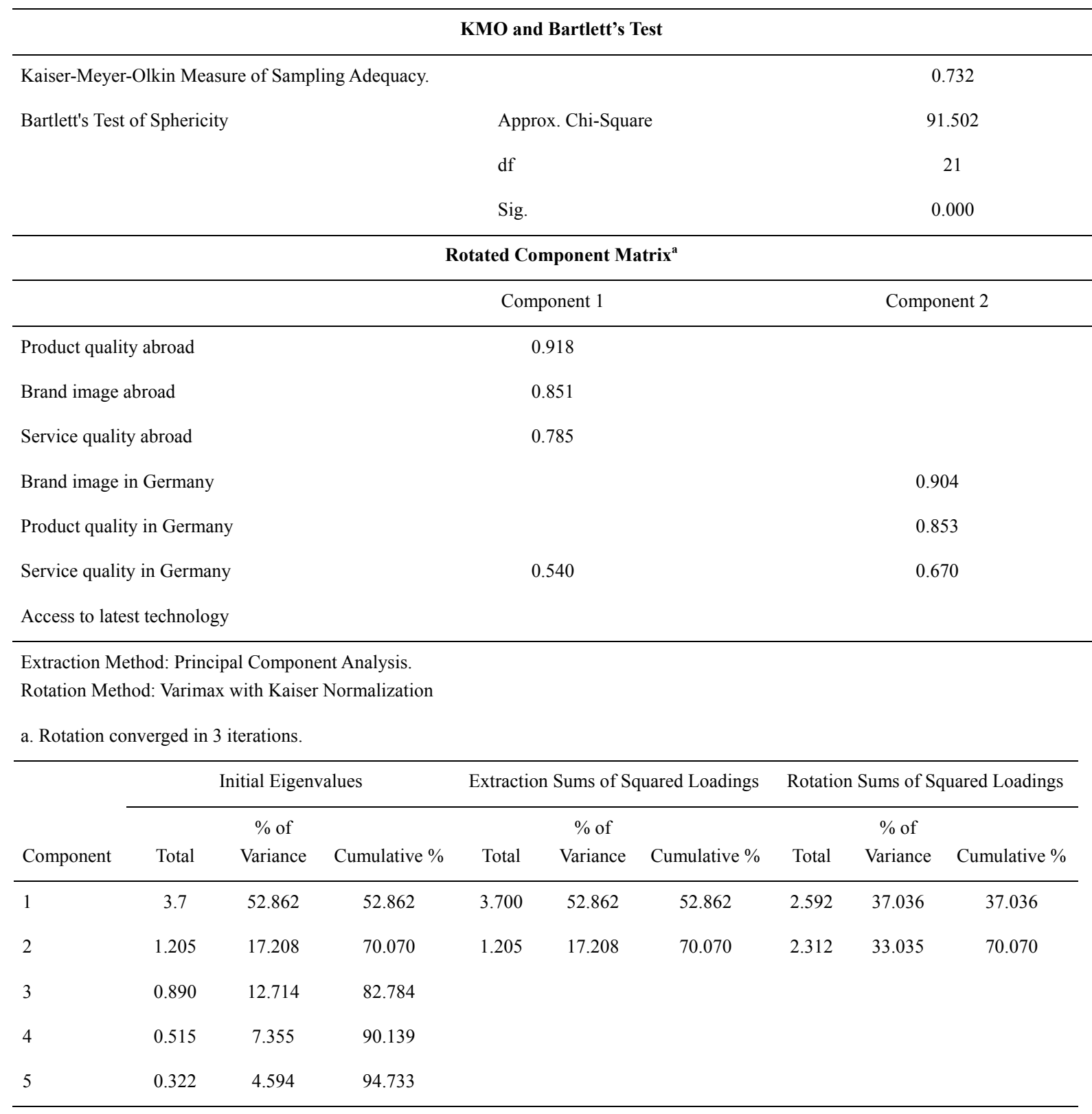




\begin{tabular}{llll}
\hline 6 & 0.219 & 3.134 & 97.868 \\
7 & 0.149 & 2.132 & 100.000 \\
\hline
\end{tabular}

Extraction Method: Principal Component Analysis.

App. 2 Factor analysis of the specific competence variables

\begin{tabular}{|c|c|c|c|}
\hline \multicolumn{4}{|c|}{ KMO and Bartlett's Test } \\
\hline \multicolumn{3}{|c|}{ Kaiser-Meyer-Olkin Measure of Sampling Adequacy. } & 0.736 \\
\hline \multirow[t]{3}{*}{ Bartlett's Test of Sphericity } & Approx. Chi-Square & & 158.703 \\
\hline & df & & 45 \\
\hline & Sig. & & 0.000 \\
\hline \multicolumn{4}{|c|}{ Rotated Component Matrix ${ }^{a}$} \\
\hline & & Component 1 & Component 2 \\
\hline \multicolumn{2}{|c|}{ Cross boarder communication and exchange of ideas } & .820 & \\
\hline \multicolumn{2}{|c|}{ Measurement of international performance } & .813 & \\
\hline \multicolumn{2}{|c|}{ Analysis of international performance } & .796 & \\
\hline \multicolumn{2}{|l|}{ International experience } & -.641 & \\
\hline \multicolumn{2}{|l|}{ Entrepreneurship } & .581 & \\
\hline \multicolumn{3}{|c|}{ Use of print media (mode of market entry) } & .883 \\
\hline \multicolumn{3}{|c|}{ Experience with modes of market entry } & .803 \\
\hline \multicolumn{3}{|l|}{ Use of print media (markets) } & .752 \\
\hline \multicolumn{3}{|c|}{ Experience with internationalization of corporate functions } & .751 \\
\hline \multicolumn{2}{|l|}{ Training of employees } & .504 & .539 \\
\hline
\end{tabular}

Extraction Method: Principal Component Analysis.

Rotation Method: Varimax with Kaiser Normalization.

a. Rotation converged in 3 iterations.

\begin{tabular}{|c|c|c|c|c|c|c|c|c|c|}
\hline \multirow[b]{3}{*}{ Component } & \multicolumn{3}{|c|}{ Initial Eigenvalues } & \multicolumn{3}{|c|}{ Extraction Sums of Squared Loadings } & \multicolumn{3}{|c|}{ Rotation Sums of Squared Loadings } \\
\hline & & $\%$ of & & & $\%$ of & & & $\%$ of & \\
\hline & Total & Variance & Cumulative \% & Total & Variance & Cumulative \% & Total & Variance & Cumulative $\%$ \\
\hline 1 & 5.000 & 49.996 & 49.996 & 5.000 & 49.996 & 49.996 & 3.362 & 33.615 & 33.615 \\
\hline 2 & 1.539 & 15.386 & 65.382 & 1.539 & 15.386 & 65.382 & 3.177 & 31.767 & 65.382 \\
\hline 3 & 0.885 & 8.851 & 74.233 & & & & & & \\
\hline 4 & 0.694 & 6.942 & 81.175 & & & & & & \\
\hline 5 & 0.614 & 6.142 & 87.317 & & & & & & \\
\hline 6 & 0.478 & 4.783 & 92.100 & & & & & & \\
\hline 7 & 0.409 & 4.086 & 96.185 & & & & & & \\
\hline 8 & 0.189 & 1.889 & 98.074 & & & & & & \\
\hline
\end{tabular}




$\begin{array}{llll}9 & 0.114 & 1.145 & 99.219 \\ 10 & 0.078 & 0.781 & 100.000\end{array}$

Extraction Method: Principal Component Analysis.

App. 3 Operationalization of relative internationalisation success

No. Indicators

1 Compared to direct competition, our company in country $[\ldots]$ selected the most successful internationalisation strategy.

2 Compared to direct competition, our company in country [...] better adapted the internationalization process to the new country.

3 Please assign your company, compared to competitors in the respective country, to one of the following performance groups: lowest $20 \%$, below $20 \%$, average $20 \%$, next $20 \%$, top $20 \%$

App. 4 Factor analysis of internationalization success

\begin{tabular}{|c|c|c|c|c|c|c|}
\hline \multicolumn{7}{|c|}{ KMO and Bartlett's Test } \\
\hline \multicolumn{4}{|c|}{ Kaiser-Meyer-Olkin Measure of Sampling Adequacy. } & \multicolumn{3}{|c|}{0.642} \\
\hline \multicolumn{2}{|c|}{ Bartlett's Test of Sphericity } & \multicolumn{2}{|c|}{ Approx. Chi-Square } & \multicolumn{3}{|c|}{174.112} \\
\hline \multicolumn{4}{|c|}{$\mathrm{df}$} & \multicolumn{3}{|c|}{3} \\
\hline \multicolumn{4}{|c|}{ Sig. } & \multicolumn{3}{|c|}{0.000} \\
\hline \multicolumn{7}{|c|}{ Component Matrix ${ }^{\mathrm{a}}$} \\
\hline & & & & \multicolumn{3}{|c|}{ Component 1} \\
\hline \multicolumn{4}{|c|}{ Relative success of internationalization strategy } & \multicolumn{3}{|c|}{0.903} \\
\hline \multicolumn{4}{|c|}{ Relative success of adaption of internationalization process } & \multicolumn{3}{|c|}{0.896} \\
\hline \multicolumn{4}{|c|}{ Relative economic performance } & \multicolumn{3}{|c|}{0.730} \\
\hline \multicolumn{7}{|c|}{ Extraction Method: Principal Component Analysis. } \\
\hline \multicolumn{7}{|c|}{ a. 1 component extracted. } \\
\hline \multicolumn{7}{|c|}{ Total Variance Explained } \\
\hline & \multicolumn{3}{|c|}{ Initial Eigenvalues } & \multicolumn{3}{|c|}{ Extraction Sums of Squared Loadings } \\
\hline Component & Total & $\%$ of Variance & Cumulative \% & Total & $\%$ of Variance & Cumulative \% \\
\hline 1 & 2.151246 & 71.708 & 71.708 & 2.151 & 71.708 & 71.708 \\
\hline 2 & 0.621475 & 20.716 & 92.424 & & & \\
\hline 3 & 0.227279 & 7.576 & 100.000 & & & \\
\hline
\end{tabular}

Extraction Method: Principal Component Analysis. 
App. 5 Expectation values of $\mathrm{H} 9-\mathrm{H} 11$

\section{Expectation Value of $\mathbf{H 9}$}

\begin{tabular}{lccc}
\hline Typologies $^{\mathrm{a}}$ & Number of configuration options & Number of observed market entries & Weighted expectation value \\
\hline Company 1 - Market 1 & 2 & 3 & 0.5000 \\
Company 2 - Market 2 & 3 & 2 & 0.3333 \\
Companies 3 \& 4 - Market 3 & 2 & 83 & 0.5000 \\
\hline Total & & 88 & 0.4962 \\
\hline
\end{tabular}

a. Only observed combinations illustrated

\section{Expectation Value of $\mathrm{H10}$}

\begin{tabular}{lccc}
\hline Typologies $^{\mathrm{a}}$ & Number of configuration options & Number of observed market entries & Weighted expectation value \\
\hline Company 1 - Market 2 & 3 & 12 & 0.3333 \\
Company 1 - Market 3 & 3 & 17 & 0.3333 \\
Company 2 - Market 2 & 3 & 5 & 0.3333 \\
Companies 3 \& 4 - Market 1 & 3 & 18 & 0.3333 \\
\hline Companies 3 \& 4 - Market 2 & 3 & 50 & 0.3333 \\
\hline Total & & 102 & 0.3300 \\
\hline
\end{tabular}

a. Only observed combinations illustrated

\section{Expectation Value of H11}

\begin{tabular}{lccc}
\hline Typologies $^{\mathrm{a}}$ & Number of configuration options & Number of observed market entries & Weighted expectation value \\
\hline Company 1 - Market 1 & 2 & 3 & 0.5000 \\
Company 1 - Market 2 & 3 & 12 & 0.3333 \\
Company 1 - Market 3 & 3 & 17 & 0.3333 \\
Company 2 - Market 2 & 3 & 2 & 0.3333 \\
Companies 3 \& 4 - Market 1 & 3 & 18 & 0.3333 \\
\hline Total & & 52 & 0.3429 \\
\hline
\end{tabular}

a. Only observed combinations illustrated

App.6 Results for H9-H11

\begin{tabular}{|c|c|c|c|c|c|c|}
\hline \multicolumn{7}{|c|}{ One-Sample Statistics } \\
\hline & & $\mathrm{N}$ & $\mathrm{M}$ & \multicolumn{2}{|c|}{ Std. Deviation } & Std. Error Mean \\
\hline \multicolumn{2}{|l|}{ H9: Selection of FIT configuration } & 88 & 0.4 & 0.4 & & 0.05292 \\
\hline \multicolumn{7}{|c|}{ One-Sample Test } \\
\hline & \multicolumn{6}{|c|}{ Test Value $=0.496212121$} \\
\hline & & & & \multicolumn{3}{|c|}{$\begin{array}{l}\text { 95\% Confidence Interval of the } \\
\text { Difference }\end{array}$} \\
\hline & $\mathrm{t}$ & $\mathrm{df}$ & Sig.(2-tailed) & Mean Difference & Lower & Upper \\
\hline $\begin{array}{l}\text { H9: Selection of FIT } \\
\text { configuration }\end{array}$ & -1.431 & 87 & 0.156 & -0.07576 & -0.1809 & 0.0294 \\
\hline
\end{tabular}




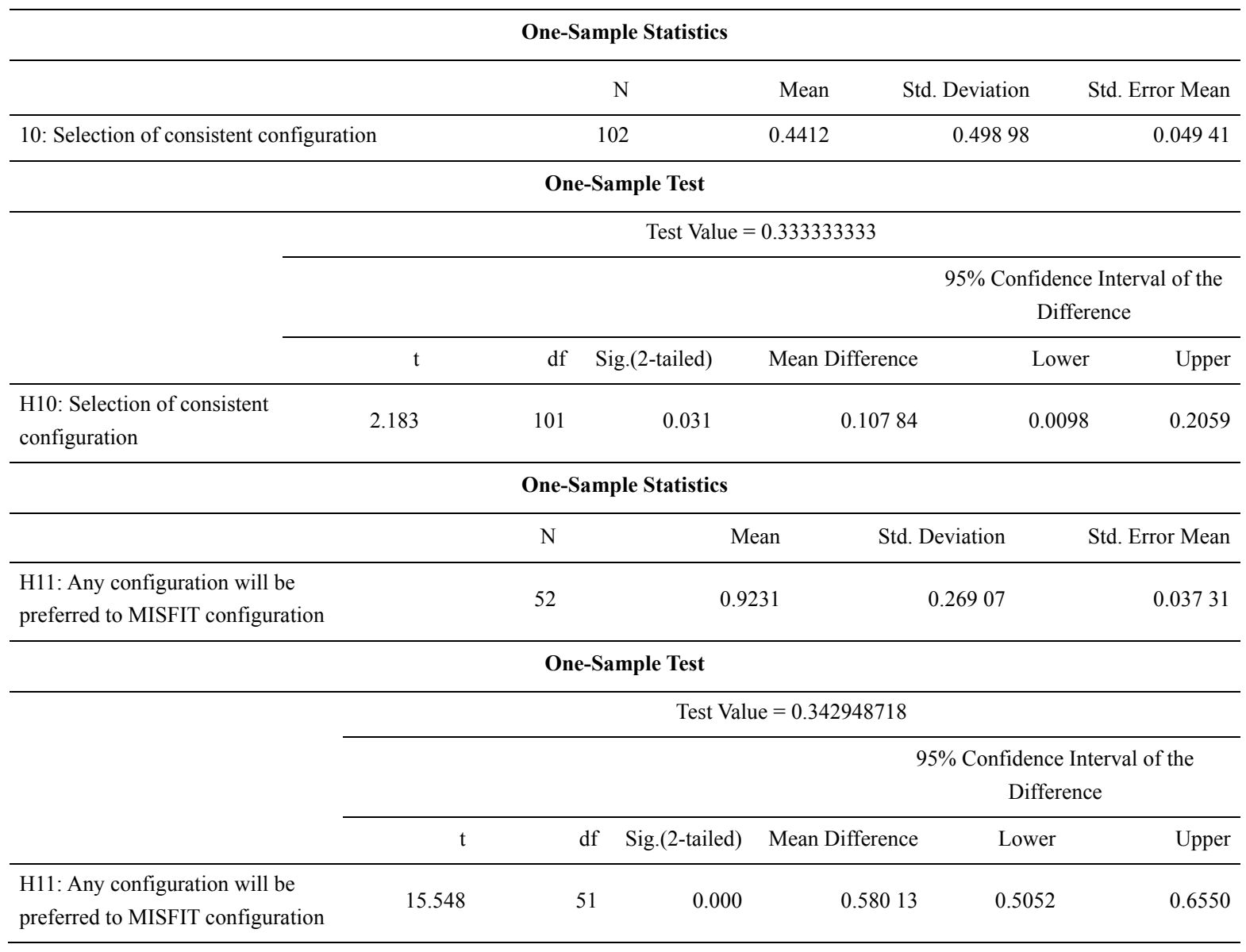

App.7 Test for multicollinearity by linear regression

Coefficients $^{\mathrm{a}}$

\begin{tabular}{|c|c|c|c|c|c|c|c|c|c|c|c|c|}
\hline \multirow[b]{2}{*}{ Model } & \multicolumn{2}{|c|}{$\begin{array}{l}\text { Unstand. } \\
\text { Coefficients }\end{array}$} & \multirow{2}{*}{$\begin{array}{c}\text { Stand. } \\
\text { Coeffici- } \\
\text { ents }\end{array}$} & \multirow{2}{*}{$\mathrm{t}$} & \multirow{2}{*}{ Sig. } & \multicolumn{2}{|c|}{$\begin{array}{c}95,0 \% \\
\text { Confidence } \\
\text { Interval for B }\end{array}$} & \multicolumn{3}{|c|}{ Correlations } & \multicolumn{2}{|c|}{$\begin{array}{l}\text { Collinearity } \\
\text { Statistics }\end{array}$} \\
\hline & B & $\begin{array}{l}\text { Std. } \\
\text { Error }\end{array}$ & & & & $\begin{array}{l}\text { Lower } \\
\text { Bound }\end{array}$ & $\begin{array}{l}\text { Upper } \\
\text { Bound }\end{array}$ & $\begin{array}{l}\text { Zero- } \\
\text { order }\end{array}$ & Partial & Part & $\begin{array}{l}\text { Toler- } \\
\text { ance }\end{array}$ & VIF \\
\hline 1 (Constant) & 1.575 & 0.124 & & 12.677 & 0.000 & 1.330 & 1.821 & & & & & \\
\hline QUALITY_ABR & -0.063 & 0.095 & -0.058 & -0.667 & 0.506 & -0.251 & 0.124 & -0.066 & -0.056 & -0.055 & 0.908 & 1.101 \\
\hline QUALITY_GER & -0.028 & 0.078 & -0.031 & -0.358 & 0.721 & -0.183 & 0.127 & 0.014 & -0.030 & -0.029 & 0.887 & 1.127 \\
\hline ORG_MAT & 0.152 & 0.119 & 0.121 & 1.275 & 0.204 & -0.084 & 0.388 & 0.088 & 0.107 & 0.105 & 0.746 & 1.341 \\
\hline PROF_INT & 0.141 & 0.080 & 0.163 & 1.764 & 0.080 & -0.017 & 0.300 & 0.160 & 0.147 & 0.145 & 0.792 & 1.262 \\
\hline MARKET_RISK & 0.051 & 0.143 & 0.029 & 0.354 & 0.724 & -0.232 & 0.333 & 0.035 & 0.030 & 0.029 & 0.985 & 1.015 \\
\hline MARKET_POT & 0.140 & 0.094 & 0.123 & 1.486 & 0.139 & -0.046 & 0.326 & 0.134 & 0.125 & 0.122 & 0.989 & 1.011 \\
\hline ZREVENUES & -0.127 & 0.199 & -0.065 & -0.636 & 0.526 & -0.520 & 0.267 & 0.039 & -0.054 & -0.052 & 0.647 & 1.546 \\
\hline
\end{tabular}

a. Dependent Variable: Mode of market entry. 


\section{Copyrights}

Copyright for this article is retained by the authors, with first publication rights granted to the journal.

This is an open-access article distributed under the terms and conditions of the Creative Commons Attribution license (http://creativecommons.org/licenses/by/3.0/). 